\title{
Significance of placental pathology in transplacental haemorrhage
}

\author{
BANTI DEVI, R. F. JENNISON, AND F. A. LANGLEY \\ From the Department of Obstetrics and Gynaecology, University of Manchester, \\ and of Pathology, St Mary's Hospitals, Manchester
}

SYNOPSIS Placentae were examined from 120 women whose pregnancy and delivery was normal, ì from 264 women whose pregnancy or delivery was complicated, and from 98 women who were $\vec{\omega}$ Rh-negative without antibodies and 35 women Rh-negative with antibodies. The presence of Kline's haemorrhages, intervillous thrombi, infarcts, and retroplacental haemorrhages was positively correlated with the presence of foetal cells in the maternal circulation. When there were no maternal antibodies transplacental haemorrhages occurred occasionally in the absence of such placental lesions but more frequently when these lesions were present. Moreover, the greater the number of lesions in a placenta the greater the size of the transplacental haemorrhage. In Rh-negative women with antibodies the observed incidence of transplacental haemorrhage was significantly less despite an appreciable increase in placental lesions.

There is no direct anatomical communication between the maternal and foetal blood vessels in the placenta. Nevertheless, the not infrequent occurrence of transplacental foeto-maternal haemorrhage indicates that such communication must take place from time to time. The nature and mechanism of this leak is not understood. The object of the present investigation was to determine what relation, if any, exists between certain easily recognizable placental lesions and transplacental haemorrhages. The lesions considered were infarction, retroplacental haematoma, Kline's haemorrhage, and intervillous thrombosis. The following is a brief description of these lesions.

\section{INFARCTION}

A placental infarct is a circumscribed area of necrosis of villi presumably caused by local obstruction of the maternal circulation. Infarcts may occur anywhere in the placenta and vary greatly in shape and size. Usually they are triangular; one edge of the infarct is usually formed by the basal plate. A fresh infarct has a reddish, or rusty-brown, appearance and is firmer than the adjacent placental tissue. As the infarct ages it becomes firmer and its colour changes successively from red to brown, to yellow and eventually to white. Microscopically (Fig. 1) the very

Received for publication 7 August 1967. early infarct is characterized by crowding of villi and narrowing of the intervillous space. The foetal vessels are dilated and congested. As the infarct ages the villi undergo necrosis until in the late stage they have a 'ghost-like' appearance. Sometimes the margin of the infarct is infiltrated with polymorphonuclear leucocytes and histiocytes. More detailed descriptions are given by Fox (1963) and Wilkin (1965).

\section{RETROPLACENTAL HAEMATOMA}

A retroplacental haematoma is formed by blood insinuating itself between the placenta proper and the decidua basalis. If the placenta is delivered soon after the haemorrhage has occurred it shows a $N$ depression on the maternal surface with firmly attached blood clot. Older clots are firm, brown and laminated and indent the placental tissue. Microscopically (Fig. 2) a recent retroplacental haematoma consists largely of red blood cells with a few strands of fibrin. As the haematoma ages the red cells degenerate and the fibrin framework becomes more conspicuous. Occasionally the basal plate ruptures and the haematoma comes into direct contact with the placental villi. Placental infarction is often a

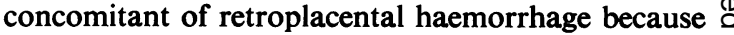
the maternal blood supply to the overlying villi is interrupted. 


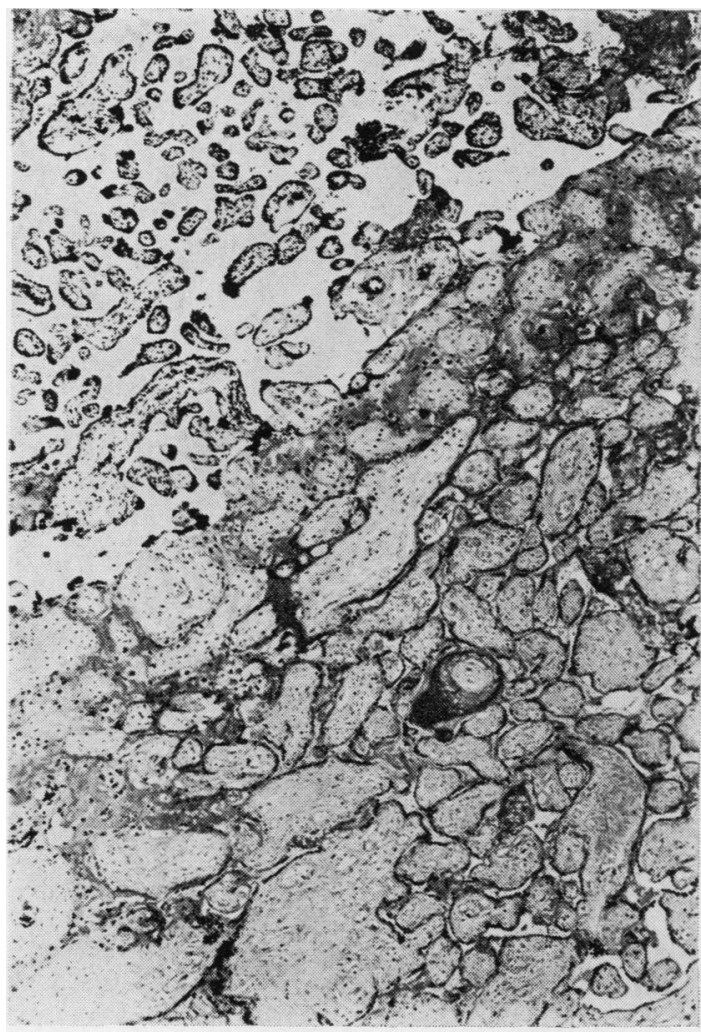

FIG. 1. Placental infarct. The villi are crowded together and swollen in the infarcted area and the intervillous space is obliterated $(H \& E \times 45)$.

\section{KLINE'S HAEMORRHAGE}

Kline (1948) described 'numerous breaks in the barrier associated with haemorrhage from the foetal circulation into the maternal intervillous space' but did not give a very clear description of the macroscopic appearance of these lesions. Wentworth (1964) has interpreted them as haemorrhagic areas usually, but not always, located near the centre of a cotyledon and this is the sense in which the term 'Kline's haemorrhage' is used in this paper. On slicing a placenta they appear as collections of fluid blood; they are usually located about half way between the foetal and maternal surfaces but they can be subchorionic or lie near the decidua. The situation of some of them suggests that they may not be haemorrhages but merely pools of blood in the relatively villus-free centres of the tambour-shaped foetal cotyledons, described by Wilkin (1965) (Fig. 3). Wilkin uses the term 'caverne' to describe this lesion, and Spanner (1936) called it 'plazentar-Hohlraum'.

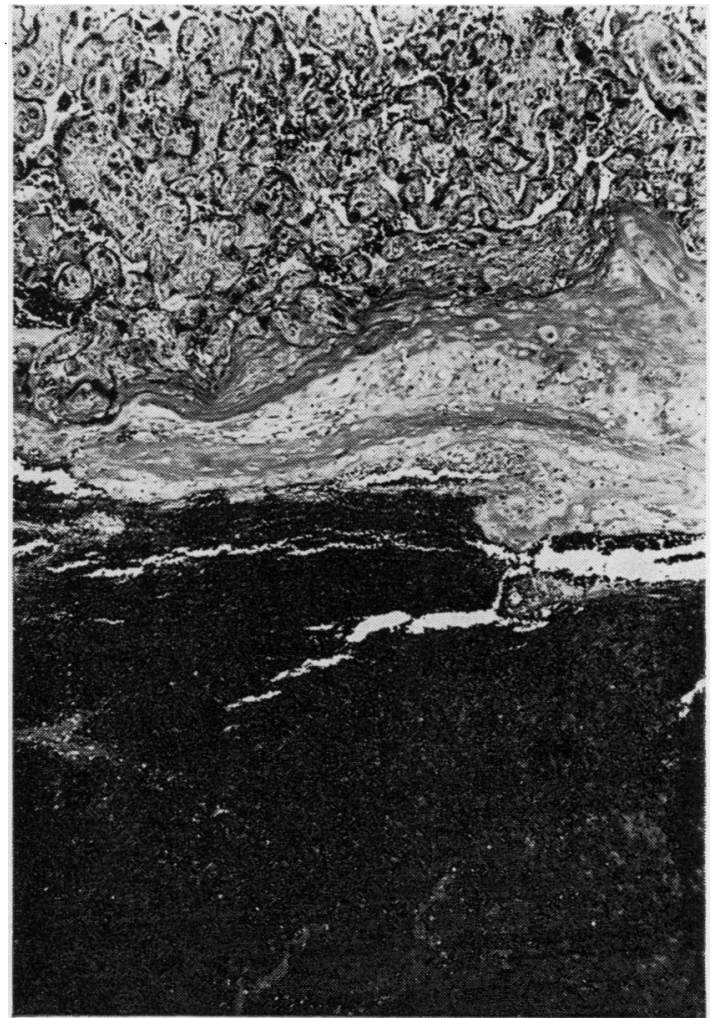

FIG. 2. Retroplacental haematoma. The haematomalies below and the infarcted placenta with crowded villi is above $(H \& E \times 45)$.

\section{INTERVILLOUS THROMBOSIS}

Intervillous thrombi occur in similar sites to Kline's haemorrhages but a few may be found near the basal plate. Generally they are 1 to $3 \mathrm{~cm}$ in diameter. A placenta may contain a single thrombus or as many as twenty. They are composed of coagulated blood and are characterized by yellowish laminae traversing the red clot (Fig. 4). In old thrombi the laminae increase in width until the whole lesion is uniformly white. Microscopically the appearances in the initial stages are those of coagulated blood. The red cells are not haemolysed, the white cells are well preserved, and the fibrin is not laminated. As the lesion ages the red cells degenerate and the fibrin becomes more conspicuous and arranged in striae (Fig. 5). The neighbouring villi are pushed back and none are present within the lesion, but there is often a rim of compressed, infarcted villi at the periphery. The lesion is not a thrombus in the strict sense of the word since there is no deposit of platelets. 
FIG. 3. Kline's haemorrhage. The section is taken from the margin of a haemorrhagic area near the centre of a cotyledon $(H \& E \times 45)$.

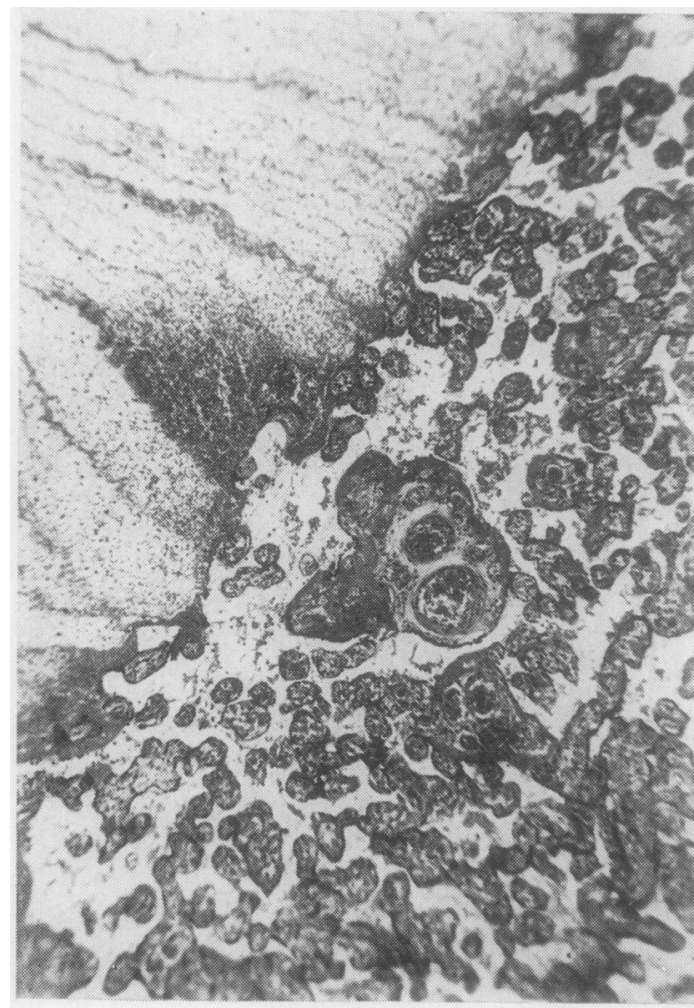

FIG. 5. Late intervillous thrombus. The thrombus is now composed largely of fibrin arranged in strands $(H \& E \times 45)$.

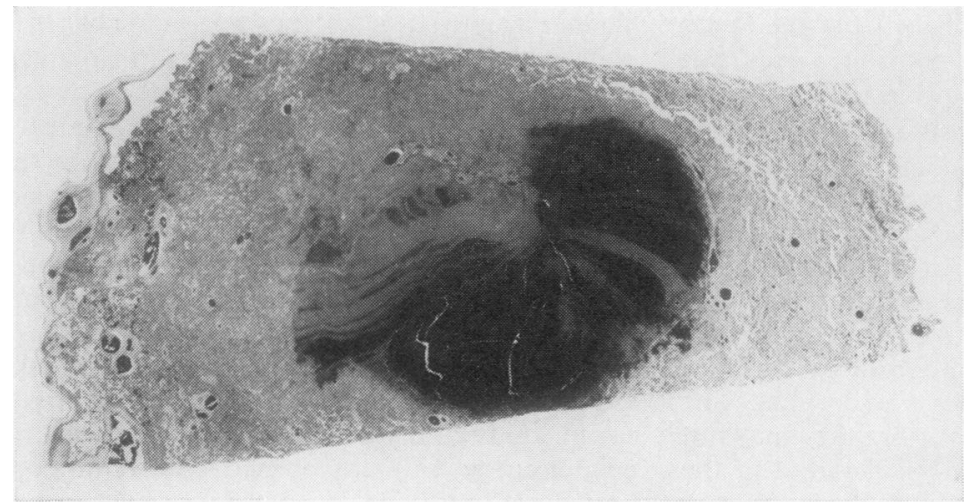

FIG. 4. Intervillous thrombus situated about midway between the foetal and maternal surfaces of the placenta. Laminae of fibrin traverse the blood clot $(H \& E \times 2)$. 
Microscopically recognizable lesions such as breaks in the trophoblastic layer were fairly frequently seen in this study. It is possible that such breaks were artefacts produced during delivery of the placenta, handling, cutting, or histological preparation. In this investigation, breaks in continuity were discounted unless they were in the central part of a section where rupture during cutting and preparation is less likely to occur. A characteristic feature is the presence of a blob of fibrinous material at the margin of the break. Fox (1963) suggested that the small

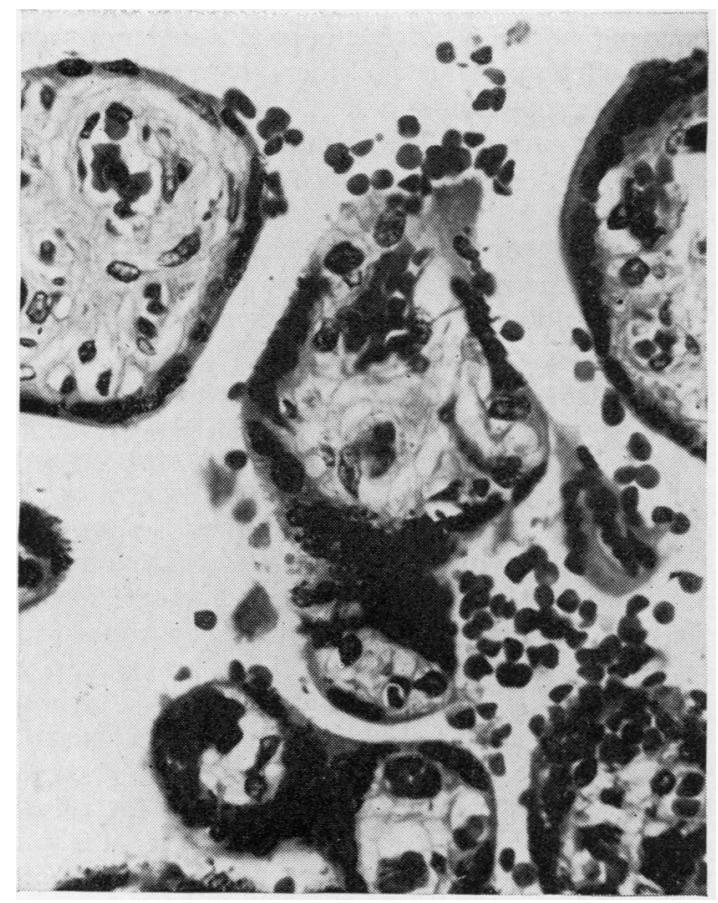

FIG. 6. Rupture of the trophoblastic-endothelial junction near an area of placental infarction. Note the blob of fibrin on the villus near the site of rupture $(H \& E \times 440)$.

blob represents an attempt to close off the syncytial break and indicates that it has been made before delivery (Fig. 6). From time to time nucleated red cells may be seen in the intervillous space (Figs. 7 and 8). They are an index of the presence of foetal blood and are, of course, not as numerous as the foetal erythrocytes themselves which are mingled with the maternal blood in the intervillous space. In histological preparations nucleated erythrocytes may be confused with lymphocytes. In this study cells were regarded as nucleated red blood cells only when a fairly broad rim of eosinophilic cytoplasm was clearly seen round the nucleus. The frequency and extent of these microscopic lesions could not be

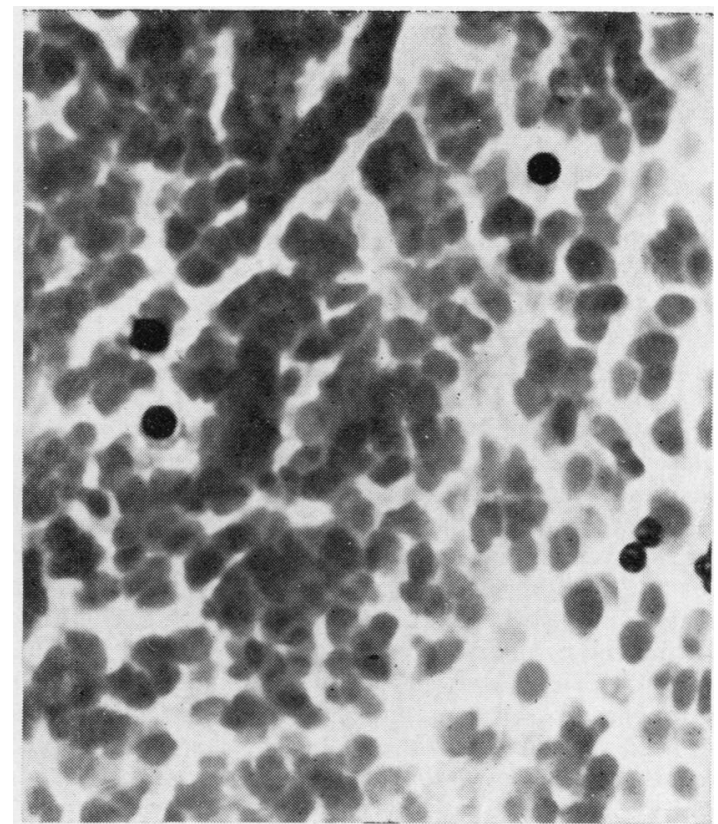

FIG. 7. Nucleated red cells in a Kline's haemorrhage $(H \& E \times 850)$.

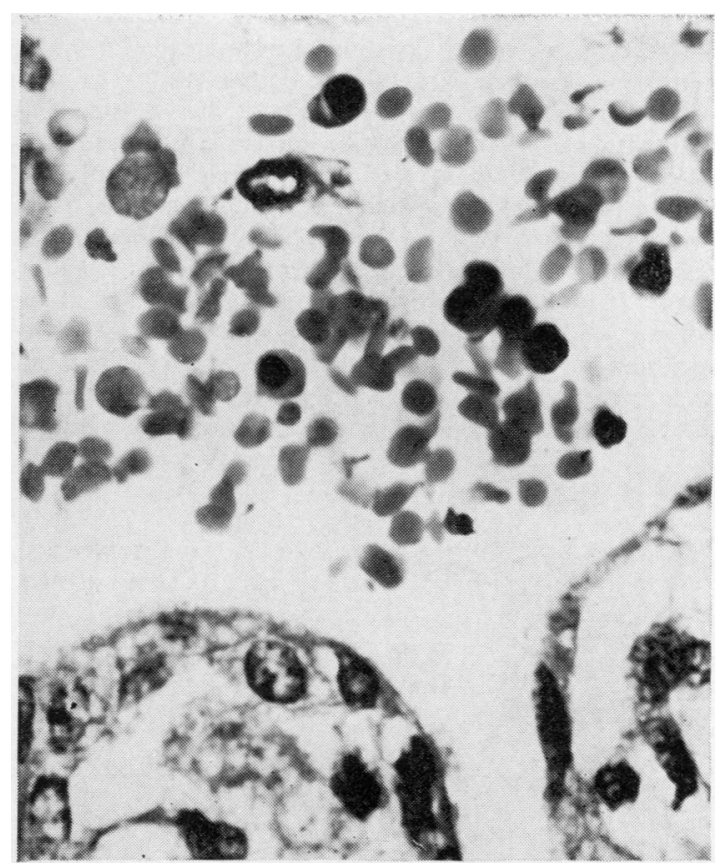

FIG. 8. Nucleated red cells in the intervillous space of an erythroblastotic placenta $(H \& E \times 850)$. 
assessed easily and hence were not correlated quantitatively with the occurrence of transplacental haemorrhage.

\section{MATERIAL AND METHODS}

Five hundred and seventeen placentae were collected from women delivered at St Mary's Hospitals, Manchester. Of these, 120 were from women delivered normally following a normal pregnancy, 264 from women whose pregnancy or delivery was 'complicated', 98 from rhesusnegative women without antibodies, and 35 from rhesusnegative women with antibodies. Soon after delivery the placentae were placed in $10 \%$ buffered formalin where they were allowed to fix for several weeks. After fixation they were weighed, measured, and cut into vertical strips $0.5 \mathrm{~cm}$ in thickness. The cut surfaces were examined for any obvious pathological lesion with the help of a magnifying lens. It should be emphasized that from time to time more than one type of lesion occurred in the same placenta. Tissue was taken for histological processing from the gross lesions and also from placentae which showed no naked-eye abnormality. Sections were stained routinely with haematoxylin and eosin, and Lendrum's M.S.B. stain for fibrin was used in selected cases.

Maternal venous blood was taken within six hours of delivery for examination for foetal cells, the presence of which was determined by Kleihauer's acid elution method (Kleihauer, Braun, and Betke, 1957). Using a citric acid-phosphate buffer at $\mathrm{pH} 3.4$ to 3.6 at $37^{\circ} \mathrm{C}$, adult haemoglobin can be eluted from adult red cells while foetal haemoglobin remains intact in the foetal cells. Foetal cells in a smear can thus be distinguished from the adult cells by their large size and their ability to stain with eosin in contrast to the ghosts of the adult cells. A blind study of 120 adult control subjects (male and nonpregnant female) compared with an equal number of postpartum women showed that a count of 2 or more foetal cells per 100 low-power fields $(\times 120)$ could be regarded as definite evidence of transplacental haemorrhage. It is difficult to make accurate estimations of the volume of a transplacental haemorrhage because of variation in maternal blood volume and in the maternal and foetal red cell counts. However, on the basis of dilution studies and on the assumption of a maternal blood volume of 5 litres it was estimated that a foetal cell count of 2 to 39 cells per 100 low-power fields corresponds to a small transplacental haemorrhage of less than $1 \mathrm{ml}$, whilst a count of $\mathbf{4 0}$ or above indicates a transplacental haemorrhage in excess of $1 \mathrm{~m} 1$. These figures do not indicate the total volume of the haemorrhage but only the amount of foetal blood circulating in the mother at a given time.

RESULTS

WOMEN DELIVERED NORMALLY AFTER A NORMAL PREGNANCY Placentae from 120 women who were delivered normally after a normal pregnancy were examined. Seventy-seven of these $(64 \%)$ had macroscopic placental lesions and in $43(36 \%)$ the placenta appeared normal. The results are summarized in Table $I$. The statistical significance was assessed using the $\chi^{2}$ test. Although transplacental haemorrhage occurred in women with no macroscopic placental lesion there was a significantly higher incidence of transplacental haemorrhage when such a lesion was present in the placenta than when it was absent (taking the $5 \%$ level as significant) and this is also true when transplacental haemorrhage is considered in relation to Kline's haemorrhage and intervillous thrombosis taken separately. It should, however, be noted that these lesions frequently occurred together. Both infarction and retroplacental haematoma were present in six placentae in addition to the other lesions and four of these were associated with a transplacental haemorrhage of varying magnitude $(0.25-2 \cdot 0 \mathrm{ml})$. Infarction alone was seen in six other placentae and in three of these it was associated with transplacental haemorrhage. One of them showed a foetal cell count of 238, indicating a haemorrhage of about $6 \mathrm{ml}$ of foetal blood, and about $10 \%$ of the placenta in this case was infarcted. Of the seven retroplacental haematomas, five were associated with a transplacental haemorrhage of between 0.25 and $2.0 \mathrm{ml}$ of foetal blood.

TABLE I

CORRELATION OF TRANSPLACENTAL HAEMORRHAGE WITH MACROSCOPIC LESIONS IN 120 NORMAL PREGNANCIES AND DELIVERIES

\begin{tabular}{|c|c|c|c|c|c|c|c|}
\hline \multirow{3}{*}{$\begin{array}{l}\text { Type of } \\
\text { Lesion }\end{array}$} & \multicolumn{3}{|c|}{ Lesions Present } & \multicolumn{3}{|c|}{ Lesions Absent } & \multirow{3}{*}{$P$} \\
\hline & \multicolumn{2}{|c|}{$\begin{array}{l}\text { Foetal Cell } \\
\text { Count }\end{array}$} & \multirow{2}{*}{$\begin{array}{l}\text { Incidence of } \\
\text { Transplacental } \\
\text { Haemorrhage } \\
(\%)\end{array}$} & \multicolumn{2}{|c|}{$\begin{array}{l}\text { Foetal Cell } \\
\text { Count }\end{array}$} & \multirow{2}{*}{$\begin{array}{l}\text { Incidence of } \\
\text { Transplacental } \\
\text { Haemorrhage } \\
(\%)\end{array}$} & \\
\hline & $<2$ & $>2$ & & $<2$ & $>2$ & & \\
\hline \multirow{3}{*}{$\begin{array}{l}\text { All types } \\
\text { Kline's } \\
\text { haemorrhages } \\
\text { Intervillous } \\
\text { thrombosis }\end{array}$} & 39 & 38 & $49 \cdot 3$ & 37 & 6 & 13.9 & $<0.05$ \\
\hline & 20 & 22 & $53 \cdot 3$ & 56 & 22 & $28 \cdot 2$ & $<0.05$ \\
\hline & 19 & 25 & 56.8 & 57 & 19 & $25 \cdot 0$ & $<0.01$ \\
\hline
\end{tabular}

Foetal cell count $=$ no. of cells per 100 low-power $(\times 120)$ fields. 
TABLE II

CORRELATION OF TRANSPLACENTAL HAEMORRHAGE WITH MACROSCOPIC PLACENTAL LESIONS IN 264 WOMEN WITH COMPLICATED PREGNANCIES OR DELIVERIES

Complication

\begin{tabular}{|c|c|c|}
\hline $\begin{array}{l}\text { Foetal Cell } \\
\text { Count }\end{array}$ & & $\begin{array}{l}\text { Inciden } \\
\text { Transp }\end{array}$ \\
\hline$<2$ & $>2$ & \\
\hline $\begin{array}{l}10 \\
13 \\
18\end{array}$ & $\begin{array}{l}27 \\
19 \\
25\end{array}$ & $\begin{array}{l}72 \cdot 8 \\
59 \cdot 4 \\
58 \cdot 1\end{array}$ \\
\hline $\begin{array}{r}10 \\
3\end{array}$ & $\begin{array}{r}18 \\
7\end{array}$ & $\begin{array}{l}64 \cdot 2 \\
70.0\end{array}$ \\
\hline $\begin{array}{r}6 \\
39\end{array}$ & $\begin{array}{l}11 \\
38\end{array}$ & $\begin{array}{l}64 \cdot 6 \\
49 \cdot 3\end{array}$ \\
\hline
\end{tabular}

\begin{tabular}{ll} 
Lesions Absent & \\
\hline Foetal Cell & $\begin{array}{l}\text { Incidence of } \\
\text { Transplacental } \\
\text { Haemorrt } \\
(\%)\end{array}$ \\
\hline &
\end{tabular}

\begin{tabular}{|c|c|c|c|c|c|c|c|}
\hline $\begin{array}{l}\text { Forceps } \\
\text { Caesarean section } \\
\text { Induction of labour }\end{array}$ & $\begin{array}{l}10 \\
13 \\
18\end{array}$ & $\begin{array}{l}27 \\
19 \\
25\end{array}$ & $\begin{array}{l}72 \cdot 8 \\
59 \cdot 4 \\
58 \cdot 1\end{array}$ & $\begin{array}{l}12 \\
12 \\
26\end{array}$ & $\begin{array}{l}5 \\
4 \\
6\end{array}$ & $\begin{array}{l}29 \cdot 4 \\
25 \cdot 0 \\
18 \cdot 6\end{array}$ & $\begin{array}{l}<0.01 \\
<0.05 \\
<0.001\end{array}$ \\
\hline $\begin{array}{l}\text { Pre-eclamptic } \\
\text { toxaemia }\end{array}$ & 10 & 18 & $64 \cdot 2$ & 18 & 6 & $25 \cdot 0$ & $<0.02$ \\
\hline $\begin{array}{l}\text { Breech } \\
\text { Ante-partum }\end{array}$ & 3 & 7 & $70 \cdot 0$ & 3 & 2 & $40 \cdot 0$ & $\begin{array}{l}\text { Too few to } \\
\text { estimate } P\end{array}$ \\
\hline $\begin{array}{l}\text { haemorrhage } \\
\text { Normal (from Table I) }\end{array}$ & $\begin{array}{r}6 \\
39\end{array}$ & $\begin{array}{l}11 \\
38\end{array}$ & $\begin{array}{l}64 \cdot 6 \\
49 \cdot 3\end{array}$ & $\begin{array}{r}3 \\
37\end{array}$ & $\begin{array}{l}0 \\
6\end{array}$ & $\begin{array}{l}0 \\
13.9\end{array}$ & $\begin{array}{l}\text { estımate P } \\
<0.05\end{array}$ \\
\hline
\end{tabular}

COMPLICATED PREGNANCIES AND DELIVERIES The placentae from 264 women with various complications of pregnancy or delivery were examined. The results are summarized in Table II. As in the normal series the occurrence of macroscopic placental lesions is associated with an increased incidence of transplacental haemorrhage. Of the 264 placentae examined, lesions were seen in $167(63.2 \%)$ of which $107(40.5 \%)$ were associated with demonstrable transplacental haemorrhage in the mother. Although the proportion of placentae with lesions is almost the same in the two groups, normal and complicated, the incidence of transplacental haemorrhage is significantly greater in the complicated group than in the normal group (Table III) and this applies to all types of complication with the possible exception of antepartum haemorrhage, although the number of women with this complication was small. Moreover,

\section{TABLE III}

COMPARISON OF THE INCIDENCE OF TRANSPLACENTAL HAEMORRHAGE IN NORMAL AND COMPLICATED PREGNANCIES AND DELIVERIES

\begin{tabular}{|c|c|c|c|c|c|}
\hline \multirow{3}{*}{$\begin{array}{l}\text { Macroscopic } \\
\text { Lesion }\end{array}$} & \multicolumn{2}{|c|}{ Normal } & \multicolumn{2}{|c|}{ Complicated } & \multirow{3}{*}{$\boldsymbol{P}$} \\
\hline & \multicolumn{2}{|c|}{$\begin{array}{l}\text { Transplacental } \\
\text { Haemorrhage }\end{array}$} & \multicolumn{2}{|c|}{$\begin{array}{l}\text { Transplacental } \\
\text { Haemorrhage }\end{array}$} & \\
\hline & Absent & Present & Absent & Present & \\
\hline $\begin{array}{c}\text { Absent } \\
\text { Present }\end{array}$ & $\begin{array}{l}37 \\
39\end{array}$ & $\begin{array}{r}6 \\
38\end{array}$ & $\begin{array}{l}74 \\
60\end{array}$ & $\begin{array}{r}23 \\
107\end{array}$ & $\begin{array}{l}<0.2 \\
<0.05\end{array}$ \\
\hline Total & 76 & 42 & 134 & 130 & $<0.01$ \\
\hline
\end{tabular}

the frequency and extent of the individual lesions in the complicated group is greater than in the normal. Thus Kline's haemorrhages occurred in $42.8 \%$ of placentae in the complicated group and in $35.0 \%$ of the normal group, but in the complicated group the number of Kline's haemorrhages in each placenta varied from one to 30 whereas in the normal group it only varied from one to 12 . Likewise intervillous thrombosis occurred in $40.5 \%$ of placentae in the complicated group and $36.7 \%$ of the normal group but in the complicated group the thrombi present in a placenta varied from one to 24 , and in size from 0.2 to $3.0 \mathrm{~cm}$ in diameter whereas in the normal group the thrombi in a placenta varied from one to eight and their size from 0.5 to $2.0 \mathrm{~cm}$. The majority of thrombi were recent. Figure 9 shows a close correlation between the foetal cell counts and the number of intervillous thrombi. A similar correlation obtained between Kline's haemorrhages and the size of the transplacental haemorrhage (Fig. 10). In the complicated cases infarcts were found in 26 placentae $(9.8 \%)$ and retroplacental haematomas in 24 placentae $(9.0 \%)$. Both lesions were usually present in the same placenta. These lesions were associated with a high incidence of transplacental haemorrhage (Table IV). A large area of infarction, unassociated with retroplacental haemorrhage, was found in one

\section{TABLE IV}

TRANSPLACENTAL HAEMORRHAGE IN RELATION TO PLACENTAL INFARCTION AND RETROPLACENTAL HAEMATOMA IN COMPLICATED PREGNANCIES AND DELIVERIES

\begin{tabular}{lll} 
& $\begin{array}{l}\text { Number with } \\
\text { Lesion }\end{array}$ & $\begin{array}{l}\text { Number with } \\
\text { Transplacental } \\
\text { Haemorrhage }\end{array}$ \\
\hline $\begin{array}{l}\text { Infarction } \\
\begin{array}{c}\text { Retroplacental } \\
\text { haematoma }\end{array}\end{array}$ & 26 & $19(73 \cdot 1 \%)$ \\
\end{tabular}

placenta after Caesarean section; this was associated with a transplacental haemorrhage of the order of $50 \mathrm{ml}$. Another woman delivered by forceps had a transplacental haemorrhage of similar size; her placenta showed a few intervillous thrombi in addition to the area of infarction. Transplacental leaks of 4 and $17 \mathrm{ml}$ were observed at delivery in two women with pre-eclamptic toxaemia and their placentae showed extensive areas of infarction without any other lesion.

Of 20 placentae examined from women with 


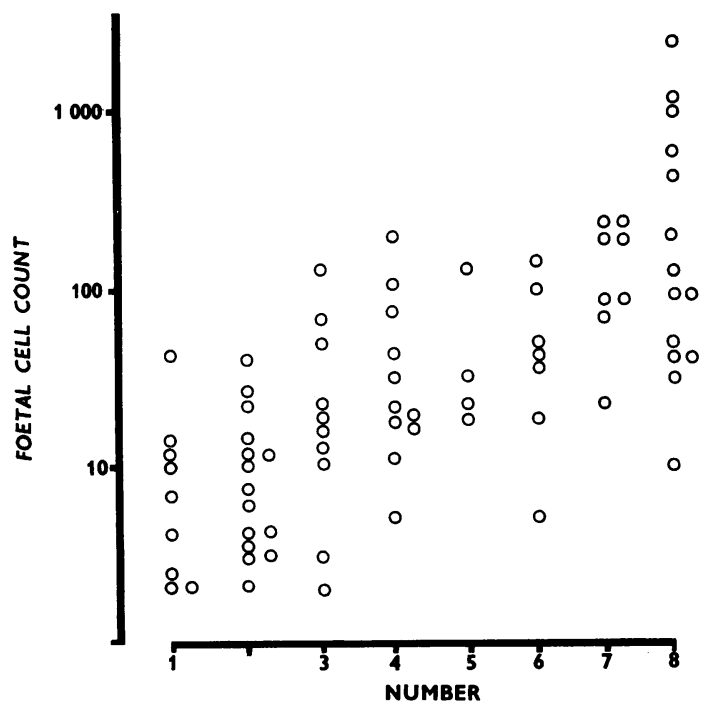

FIG. 9. The relation between the foetal cell count (log scale) of the maternal blood and the number of intervillous thrombi in the group of women with complicated pregnancies or deliveries.

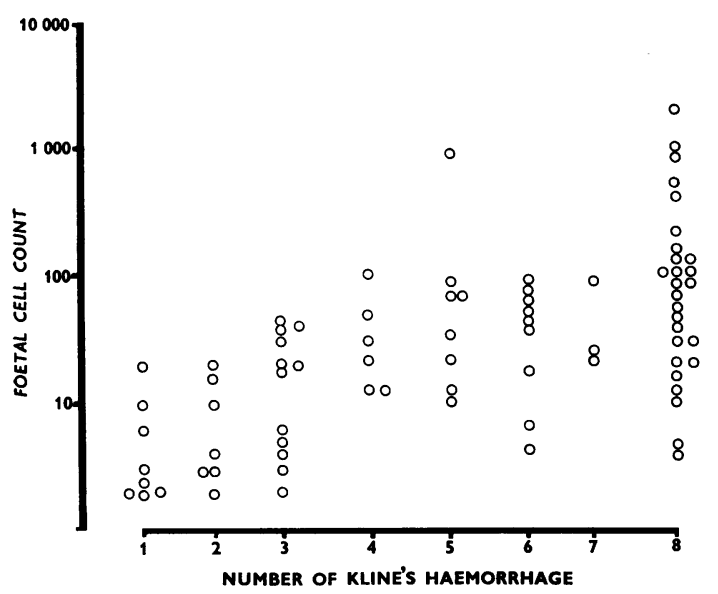

FIG. 10. The relation between the foetal cell count (log scale) in the maternal blood and the number of Kline's haemorrhages in the corresponding placenta in the group of women with complicated pregnancies or deliveries.

antepartum haemorrhage eight had retroplacental haematomas and six were associated with transplacental haemorrhage. In three, the placenta showed retroplacental haematomas only; in one, there was also an area of infarction while, in the remaining two, infarction, intervillous thrombi, and Kline's haemorrhages were also present. The magnitude of the leak in these women was from 0.5 to $5 \mathrm{ml}$ of foetal blood. One woman, after an assisted breech delivery, had a transplacental haemorrhage of about $5 \mathrm{ml}$ and her placenta showed a large retroplacental haematoma occupying about half the maternal surface; no other lesions were seen.

RH-NEGATIVE WOMEN WITHOUT ANTIBODIES Ninetyeight placentae from Rhesus-negative women with an $\mathrm{ABO}$ compatible foetus were studied. None of these women had $\mathrm{Rh}$ antibodies during pregnancy or at delivery, but the group was otherwise unselected for type of pregnancy and mode of delivery. The placentae of $66(67.3 \%)$ of these women showed one or more macroscopic lesions and 34 of these were associated with a transplacental haemorrhage. The results are summarized in Table $\mathrm{V}$. They are essentially the same as the normal group (Table I) and the individual lesions followed the same pattern, that is, there was close correlation between the number of Kline's haemorrhages and intervillous thrombi and the size of the transplacental haemorrhage (Fig. 11).

\section{TABLE V}

CORRELATION OF TRANSPLACENTAL HAEMORRHAGE WITH MACROSCOPIC PLACENTAL LESIONS (RH-NEGATIVE WOMEN WITHOUT RH ANTIBODIES)

\begin{tabular}{lllll}
$\begin{array}{l}\text { Placental } \\
\text { Lesions }\end{array}$ & $\begin{array}{l}\text { Foetal Cell } \\
\text { Count }\end{array}$ & Total & $\begin{array}{l}\text { Incidence of } \\
\text { Transplacental } \\
\text { Haemorrhage } \\
(\%)\end{array}$ \\
\cline { 2 - 5 } & $<2$ & $>2$ & & $\begin{array}{l}\text { (\%) } \\
\text { Present }\end{array}$ \\
Absent & 32 & 34 & 66 & $\begin{array}{l}51 \cdot 5 \\
18.7\end{array}$
\end{tabular}

Seventy-nine of the Rh-negative women bore Rh-positive babies and sera were examined for the development of $\mathrm{Rh}$ antibodies at least six weeks after delivery in every case. Forty of these women had macroscopic lesions in the placenta and in 25 $(62.5 \%)$ there was a demonstrable transplacental haemorrhage at delivery. Ten of the 40 women in this group had developed $\mathrm{Rh}$ antibodies by the sixth week after delivery and in eight of these there was evidence of transplacental haemorrhage. The leaks were large,

\section{TABLE VI}

TRANSPLACENTAL HAEMORRHAGE AND PLACENTAL PATHOLOGY IN RELATION TO THE DEVELOPMENT OF ANTIBODIES (RH-NEGATIVE WOMEN WITHOUT RH ANTIBODIES

\begin{tabular}{|c|c|c|c|c|c|}
\hline \multirow[b]{2}{*}{$\begin{array}{l}\text { Placental } \\
\text { Lesions }\end{array}$} & \multirow[b]{2}{*}{$\begin{array}{l}\text { Transplacental } \\
\text { Haemorrhage }\end{array}$} & \multicolumn{3}{|c|}{$\begin{array}{c}\text { AT DELIVERY) } \\
\text { Rh Antibodies }\end{array}$} & \multirow[b]{2}{*}{$\begin{array}{l}\text { Incidence of } \\
\text { Antibody } \\
\text { Formation }(\%)\end{array}$} \\
\hline & & Present & Absent & Total & \\
\hline Present & $\begin{array}{l}\text { Present } \\
\text { Absent }\end{array}$ & $\begin{array}{l}8 \\
2\end{array}$ & $\begin{array}{l}17 \\
13\end{array}$ & 40 & 25 \\
\hline Absent & $\begin{array}{l}\text { Present } \\
\text { Absent }\end{array}$ & $\begin{array}{l}\mathbf{0} \\
\mathbf{0}\end{array}$ & $\begin{array}{l}10 \\
29\end{array}$ & 39 & 0 \\
\hline
\end{tabular}




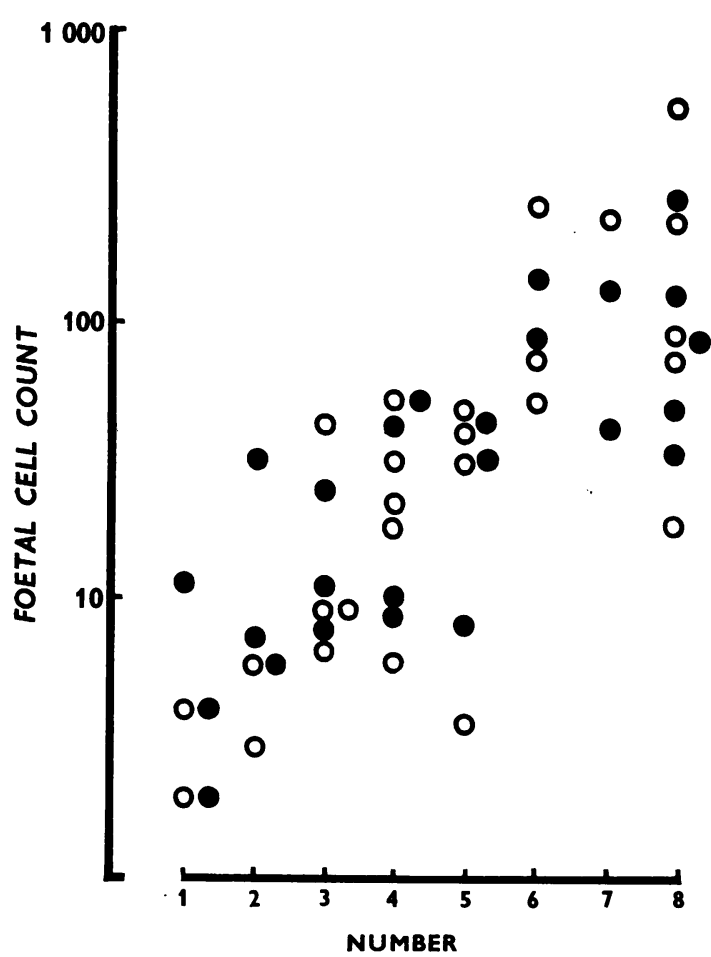

FIG. 11. The relation between the foetal cell count (log scale) and the number of Kline's haemorrhages (open circle $\bigcirc)$ and intervillous thrombi (black circle O) in the placentae of Rh-negative women without antibodies.

between $1 \mathrm{ml}$ and $15 \mathrm{ml}$, in five women. Of the 39 without placental lesions, 10 showed transplacental haemorrhage, all were less than $1 \mathrm{ml}$, and none developed antibodies (Table VI).

RH-NEGATIVE WOMEN WITH RH-ANTIBODIES The placentae from 35 women who were $R$ h-negative and had Rh-antibodies at the time of delivery were examined. Table VII shows that there is no significant relation between the occurrence of lesions and transplacental haemorrhage. Nine of the women whose placentae showed Kline's haemorrhages had a transplacental haemorrhage. The size of the leak $(0.1-2.0 \mathrm{ml})$ was independent of the number of haemorrhagic areas. Moreover, placentae from 12 women without demonstrable transplacental haemorrhage had Kline's haemorrhages varying in number from one to 16 . Likewise eight women had demonstrable transplacental haemorrhage in association with intervillous thrombi while 12 did not. Figure 12 shows that there was no correlation between the incidence of intervillous thrombi and

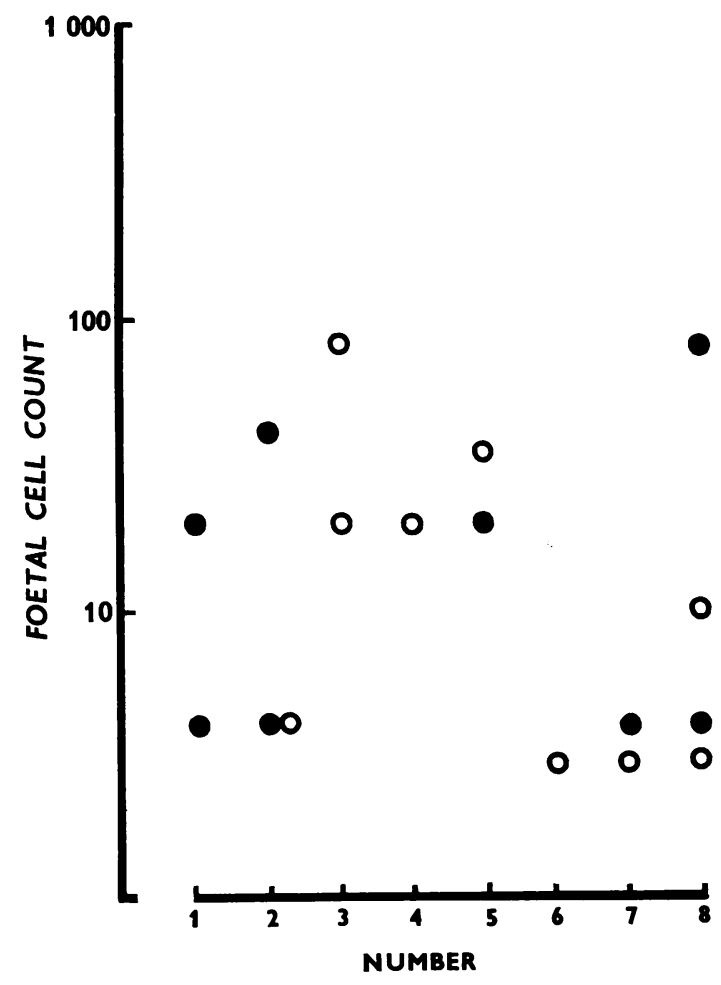

FIG. 12. The absence of any relation in Rh-negative women with antibodies between the foetal cell count in the maternal blood and the number of Kline's haemorrhages and intervillous thrombi in the placenta.

\section{TABLE VII}

CORRELATION OF TRANSPLACENTAL HAEMORRHAGE WITH MACROSCOPIC PLACENTAL LESION (RH-NEGATIVE WITH RH ANTIBODIES)

\begin{tabular}{|c|c|c|c|c|}
\hline \multirow[t]{2}{*}{$\begin{array}{l}\text { Placental } \\
\text { Lesions }\end{array}$} & \multicolumn{2}{|c|}{$\begin{array}{l}\text { Foetal Cell } \\
\text { Count }\end{array}$} & \multirow[t]{2}{*}{ Total } & \multirow{2}{*}{$\begin{array}{l}\text { Incidence of } \\
\text { Transplacental } \\
\text { Haemorrhage } \\
(\%)\end{array}$} \\
\hline & $<2$ & $>2$ & & \\
\hline $\begin{array}{l}\text { Present } \\
\text { Absent }\end{array}$ & $\begin{array}{r}18 \\
5\end{array}$ & $\begin{array}{r}10 \\
2\end{array}$ & $\begin{array}{r}28 \\
7\end{array}$ & $\begin{array}{l}35 \cdot 7 \\
28 \cdot 5\end{array}$ \\
\hline
\end{tabular}

Kline's haemorrhages and the observed foetal cell counts.

MICROSCOPIC EVIDENCE OF FOETAL BLEEDING INTO THE MATERNAL CIRCULATION The microscopic evidence for leakage of foetal blood into the maternal circulation consisted of ruptured villi and the presence of nucleated erythrocytes. Breaks in the trophoblastic-endothelial junction were observed mostly in association with Kline's haemorrhages and intervillous thrombi. A few ruptured villi were seen in association with infarcts. Nucleated red cells were 
occasionally seen in an area of Kline's haemorrhage (Fig. 7), recent intervillous thrombi, and retroplacental haematoma. Figure 8 shows the presence of nucleated erythrocytes in the intervillous space of an erythroblastotic placenta.

\section{DISCUSSION}

These results indicate a close relationship between the presence of microscopic lesions in the placenta and transplacental haemorrhages, except when the mother's blood contains circulating antibodies.

KLINE'S HAEMORRHAGE The term Kline's haemorrhage used in this paper corresponds to the description given by Wentworth (1964) rather than to the vague description of Kline himself. The question may be asked as to whether or not these localized collections of blood are haemorrhages of foetal blood into the intervillous space. Alternatively they may be regions in the placenta in which there is a low density of villi and a consequent pooling of blood as in the centre of a foetal cotyledon. The present investigation offers two reasons in support of the view that these collections of blood are indeed haemorrhages: (1) nucleated foetal erythrocytes can sometimes be seen in the blood in the lesions; (2) in the absence of antibodies there is a parallel between the size of the transplacental haemorrhage and the number of Kline's haemorrhages. Our results confirm those of Wentworth (1964). If these collections of blood were the centres of cotyledons it is difficult to see why such a parallelism should exist. If it is accepted that these are haemorrhages of foetal blood then their microscopic appearances suggest that the haemorrhage is recent because there is no lysis or clotting. This implies that they probably occurred during labour or delivery. If this is so they should not be found, or found only very occasionally, in undelivered placentae; such specimens are, however, rare.

INTERVILLOUS THROMBI When there is no Rhimmunization of the mother there is an association between the frequency of intervillous thrombosis and the occurrence of transplacental haemorrhage. This relationship is quantitative in so far as the greater the number of thrombi in a placenta the greater is the foetal leak. These observations parallel those for Kline's haemorrhages. Javert (1942) and Javert and Reiss (1952) suggested that intervillous thrombi were caused by a leakage of foetal blood into the maternal blood in the intervillous space and that the mixed blood coagulated. Potter (1948) serologically typed the blood of these thrombi and denied that there are any foetal cells present. Fox (1963) sug- gested that intervillous thrombi which are not in contact with the basal plate probably mark the site $\frac{\text { o }}{-}$ of rupture of the trophoblastic covering of a villus $\overrightarrow{\vec{F}}$ with the subsequent mingling of maternal and foetal? blood. He found microscopic evidence of a break in $\frac{\mathrm{C}}{\sigma}$ $60 \%$ of the placentae in his series. The parallel in the $\frac{\bar{c}}{\mathrm{~s}}$ incidence of Kline's haemorrhages and intervillous $\overrightarrow{\mathbb{\Phi}}$ thrombi and the finding of nucleated red cells in 2 each suggests that these are closely related lesions. It 0 seems probable that intervillous thrombosis results $\overrightarrow{0}$ from entry of foetal blood into the intervillous space, $\vec{\exists}$ as in Kline's haemorrhage, and serves a protective $\vec{\sigma}$ function by limiting the extent of the foeto-maternat transfusion. The time at which intervillous thrombio form is uncertain but it is clear that the older ones must antedate the onset of labour by days or possibly $\omega$ weeks. They may therefore represent previous episodes of transplacental haemorrhage. No account ${ }_{\circ}^{N}$ was taken of the age of the thrombi when they were enumerated. Thus, because some of the thrombi $\vec{z}$ probably represent old leaks and some of Kline's haemorrhages may represent the dilated centres of foetal cotyledons rather than foeto-maternal leaks, $\ddot{\oplus}$ it is not surprising that no transplacental haemorrhage was found in a number of women whose placentae show such macroscopic changes. Indeed, 文 since leakage of foetal blood may well be episodic, the correlations recorded here are surprisingly good. مै

INFARCTION AND RETROPLACENTAL HAEMORRHAGE $\stackrel{2}{\Rightarrow}$ Zeek and Assali (1952) studied serial sections of $\frac{\circ}{3}$ 'subacute' infarcts and showed the rupture of foetal vessels and the spillage of foetal cells contiguous to the necrotic villi of the infarct. In the present study ruptured villi were sometimes seen near infarcts.? Bromberg, Salzberger, and Abrahamov (1957) de-욱 monstrated a considerable amount of foetal blood in retroplacental haematomas in a series of 41 normalo deliveries. We have also seen nucleated red cells in such haematomas.

Although infarcts and retroplacental haematomas $>$ often occur together we have shown above that transplacental haemorrhage may be associated with $N$ these lesions when they occur separately. It is pertinent to note that placental infarction is one of 0 the common accompaniments of pre-eclamptic $\omega$ toxaemia (Fox, 1967), and may account for the high incidence of transplacental haemorrhage in womenco suffering from pre-eclampsia.

PLACENTAL LESIONS IN RH-NEGATIVE WOMEN WITH T⿱一兀 RH-ANTIBODIES Javert and Reiss (1952) found a $\frac{\bar{P}}{\Phi}$ much higher incidence of intervillous thrombi in $\stackrel{\mathbb{Q}}{\square}$ placentae from erythroblastotic infants than normal. $\stackrel{1}{\Omega}$ This is a common observation and is supported by our observations. Intervillous thrombi were found $\Omega$ 
in $37.5 \%$ of placentae from normally delivered women (Table I) but in $57.1 \%$ of placentae from women with Rh-antibodies. The incidence of Kline's haemorrhages was increased in a similar manner. The cause of this increased number of lesions is not readily explained. These two possibilities exist: (1) that in the presence of $\mathrm{Rh}$-antibodies the foetal red cells leaking into the intervillous space agglutinate and haemolyse, thus releasing 'thromboplastin' and causing coagulation; (2) that cellular damage may result from an antigen-antibody reaction occurring within the trophoblast itself. Be the explanation what it may, there is clear morphological evidence in haemolytic disease of the leakage of foetal blood indicated both by the presence of Kline's haemorrhage and intervillous thrombi and the presence of nucleated erythrocytes in the intervillous space. Nevertheless, the incidence of recognizable transplacental haemorrhage in the mother's circulation was significantly less than in the normal series. This supports Mollison's hypothesis (1959) that when antibodies are present incompatible cells are rapidly removed from the circulation.

TRANSPLACENTAL HAEMORRHAGE IN THE ABSENCE OF MACROSCOPIC PLACENTAL LESIONS A few cases in each group had evidence of transplacental haemorrhage without any lesion demonstrable to the naked eye. It is probable that in these there were microscopic leaks which could have been recognized by ruptured villi and the presence of nucleated erythrocytes in the intervillous space but, as indicated previously, no attempt was made to assess such lesions quantitatively. Indeed, since the placental changes were assessed without knowing whether or not transplacental haemorrhage had occurred the labour of estimating microscopic lesions would have been prohibitive. It may be suggested that microscopic leaks are the precursors of the larger leaks which are recognizable as Kline's haemorrhages and that these, in turn, are the precursors of intervillous thrombi.

Other investigations, reported by us elsewhere, indicate that the frequency of transplacental haemorrhage during pregnancy (but before delivery) increases with the period of gestation, thus, the incidence is nearly twice as great at 36 to 42 weeks' gestation as at eight to 16 weeks. Correspondingly the trophoblastic mantle of the villi is thinned out as the placenta matures and the capillaries come to lie nearer the margin of the villi. Under these conditions relatively slight damage to the mature villi might cause a microscopic leak of foetal blood since the foetal venous pressure is higher than that in the maternal intervillous space (Reynolds, 1954).

We should like to thank Professor W. I. C. Morris for his encouragement and the facilities of his department, Mr. B. W. Figg for the photomicrographs, and Dr R. Ollerenshaw, of the Department of Medical Illustration, United Manchester Hospitals, for the charts.

\section{REFERENCES}

Bromberg, Y. M., Salzberger, M., and Abrahamov, A. (1957). Amer. J. Obstet. Gynec., 74, 674.

Fox, H. (1963). J. Obstet. Gynaec. Brit. Cwlth, 70, 980. (1967). Biol. Neonat. (Basel), 11, 87.

Javert, C. T. (1942). Surg. Gynec. Obstet., 74, 1. , and Reiss, C. (1952). Ibid., 94, 257.

Kleihauer, E., Braun, H., and Betke, K. (1957). Klin. Wschr., 35, 637. Kline, B. S. (1948). Amer. J. Obstet. Gynec., 56, 226.

Mollison, P. L. (1959). Brit. med. J., 2, 1035.

Potter, E. L. (1948). Amer. J. Obstet. Gynec., 56, 959.

Reynolds, S. R. M. (1954). Ibid., 68, 69.

Spanner, R. (1936). See Harris, B. A. (1956). Ibid., 71, 350.

Wilkin, P. (1965). Pathologie du Placenta, p. 14. Masson, Paris.

Wentworth, P. (1964). J. Obstet. Gynaec. Brit. Cwlth, 71, 379.

Zeek, P. M., and Assali, N. S. (1952). Amer. J. Obstet. Gynec., 64, 1191. 